\title{
Assessing Suitability of Fluted Roller Metering Mechanism for Cassava Setts Planter
}

\author{
M. Dinesh Pandi ${ }^{1 *}$, D. Asokan², J. John Gunasekar² and S. Vallal Kannan² \\ ${ }^{1}$ Department of Farm Machinery and Bio-Energy, ${ }^{2}$ AEC \& RI, Kumulur, \\ Trichy-621 712, India \\ *Corresponding author
}

\begin{abstract}
A B S T R A C T
\section{Keywords}

Cassava planting, Cassava sett, Fluted roller metering mechanism, Filling efficiency

Article Info

Accepted:

17 April 2019

Available Online:

10 May 2019

Manual planting of Cassava is time-consuming, unpleasant arduous job and demands a large quantity of human labour. Labor shortage is one of the major constraints in manual cassava planting in India, especially in Tamil Nadu. Study was conducted to meter the cassava setts using a fluted roller metering mechanism. A laboratory model of fluted roller metering mechanism was developed and its metering filling efficiency was evaluated. The study was carried out to design the optimum cell size at different peripheral speed on filling efficiency. The levels of speed selected for the laboratory tests were taken as 0.13 , $0.20,0.26,0.33,0.40,0.46,0.52,0.59,0.65$ and $0.72 \mathrm{~m} / \mathrm{s}$. The results revealed that when the peripheral speed exceeds $0.33 \mathrm{~m} / \mathrm{s}$, the filling efficiency begin to drop substantially for both the size ( 38.5 and $42.5 \mathrm{~mm}$ ) of cell. The maximum filling efficiency of $58 \%$ was obtained at the peripheral speed of $0.33 \mathrm{~m} / \mathrm{s}$ with the cell size of $42.50 \mathrm{~mm}$.
\end{abstract}

\section{Introduction}

Cassava (Manihot esculenta) is the most widely cultivated root crop in tropics and is grown across a broad range of agro-climatic conditions. It is native of South America and basic food for millions of people around the world. It is a shrubby perennial with stems that reaches to the height of $274 \mathrm{~cm}$ and above. The starch produced from the roots of cassava is commonly used as a food thickener and best known ingredient in tapioca pudding and many more industrial uses. In India, the cultivation of cassava is mainly done at
Kerala, Tamil Nadu, Andhra Pradesh, Meghalaya and Assam, among these states Tamil Nadu stands first both in area and production of cassava followed by Kerala and Andhra Pradesh (Varmudy, 2014).

Manual planting is an expensive and timeconsuming operation, and hence the timely planting is affected due to non-availability of labours, delaying in planting affects both quantity and quality of the tubers. However, farmers are looking forward to have an appropriate technology to plant cassava in time at low cost at affordable rate. The 
objective of this study is to check the suitability of fluted roller metering mechanism for cassava planting, as it is an easy and less maintenance one. The fluted roller metering mechanism was studied at different cell size and speed. Ryu and Kim (1998) developed a method to design the roller-type metering device for hill dropping planters. The same metering mechanism was modified and constructed for sowing oilseed rape (Ahmadi et al., 2007). Muhammad Farooq (1992) developed finger wheel mechanism for sowing the sugarcane setts.

\section{Materials and Methods}

\section{Design of fluted roller mechanism for cassava sett}

The shape and size of cell are the important parameters for designing flutted roller mechanism. The size of cell is determined based on size of setts and number of setts to be dropped per hill. Since one sett per hill is the planting procedure for cassava. Odigboh (1978) reported that receptacle shape of cell is important for the design of fluted roller to meter the cassava setts.

In this study, receptacle shape of two sizes of cell were taken as 10 percent and 25 percent more than the maximum sett dimension of single cassava sett (Table 1) by using ruling varieties in Tamil Nadu viz., Yethapur local, Srivijaya, Co4 and Cucumarose. The diameter of cells was fixed as $38.5 \mathrm{~mm}$ and $42.5 \mathrm{~mm}$ respectively (Table 2) and depth of groove $\left(\mathrm{d}_{\mathrm{g}}\right)$ was maintained as $40 \mathrm{~mm}$ for both the cells. Normally cassava sett is planted with an average length of $150 \mathrm{~mm}$ and hence, the length of grooves was fixed as $160 \mathrm{~mm}$ with $10 \mathrm{~mm}$ as allowance and welded over the surface of a cylinder at $180^{\circ}$ interval for taken for this study. Number of grooves in the metering drum was taken as four and each pair of grooves ( $a^{\prime}$ and $b^{\prime}$ ) was fixed in opposite direction at $180^{\circ}$ interval. Ryu and
Kim (1998) studied repose angle and friction angle for designing the left and right groove angle of the cell. The repose angle was determined for all the above mentioned varieties and the value was arrived as $36.5^{\circ}$. The friction angle was selected as $31^{\circ}$ which is calculated from co-efficient of static friction between cassava setts and mild steel material (Pandi et al., 2017). The left side angle of the groove was selected as $81^{\circ}$ to decrease the time delay as much as possible between the setts consecutively dropped from the grooves. The right side angle of the groove was selected as $30^{\circ}$ to give easy access to the setts into the groove. The open angle of the groove opening was $\theta \mathrm{g}=26^{\circ}$. Orthographic and isometric view of the fluted roller metering device selected is shown in figure 1.

\section{Construction of fluted roller metering mechanism test rig}

The components of cassava metering test rig includes mainframe, cassava sett metering roller, shaft, motor, feeding hopper, foam roller, cam, pulley, belts and bearings (Fig. 2). The main frame is a rectangular section of $920 \times 620 \mathrm{~mm}$ fixed at a height of $763 \mathrm{~mm}$ from ground level. Variable speed motor and sett metering disc were fitted on the sub frame. The hopper was designed to hold 200 pieces of cassava setts with an average diameter of $35 \mathrm{~mm}$. Both sides of the hopper were covered by acrylic sheet to observe the movement of sett in the metering disc as shown in figure 3. A foam roller was provided to singulate cassava setts and to fit in the cell properly. A cam mechanism was provided to the bottom of feed trough to vibrate the setts. The feed trough was hinged to the middle of the hopper and to permit one or few near the metering disc. A variable speed drive operated by a $0.5 \mathrm{~kW}$ electric motor was mounted on the sub frame. The motor speed was reduced from 1,500 rpm to the required level of 10 to $55 \mathrm{rpm}$. 


\section{Experimental procedure for laboratory testing}

Cassava setts having the diameter in the range of 30 to $35 \mathrm{~mm}$ gave better results in germination and sett length of $150 \mathrm{~mm}$ was taken for conducting laboratory trails. The hopper was filled with cassava setts and the metering drum was driven at different speeds. For each experimental run the number of setts discharged was noted with respect to time. While studying the metering efficiency of $38.5 \mathrm{~mm}$ cells size the other two bigger cells of size $42.5 \mathrm{~mm}$ were kept closed.

Similarly while using the $42.5 \mathrm{~mm}$ cells the other two $38.5 \mathrm{~mm}$ cells were kept closed. The metering efficiency of each cell was evaluated based on filling efficiency (equation 1) which is calculated based on the actual number of setts delivered comparing with the number setts expected based on design (Odigboh, 1978).

F.E. $=\mathrm{C}_{\mathrm{a}} / \mathrm{C}_{\mathrm{e}}{ }^{*} 100$

$\mathrm{C}_{\mathrm{a}}=$ Actual number of setts delivered

$\mathrm{C}_{\mathrm{e}}=$ Number of setts expected design

\section{Results and Discussion}

The effect of speed and size of the cell on filling efficiency of the metering roller at different speeds are presented in Table 1 and
2. The maximum filling efficiencies obtained in cell sizes of 38.50 and $42.50 \mathrm{~mm}$ were recorded as 48 and $58 \%$ respectively at 20 $\mathrm{rev} / \mathrm{min}$. While increasing the peripheral speed above $20 \mathrm{rev} / \mathrm{min}$ it is recorded that there is a drop in filling efficiency substantially. Odigboh (1978) also reported that drop in filling efficiency by increasing the peripheral speed.

The result revealed that $42.50 \mathrm{~mm}$ cell size has higher filling efficiency than the $38.5 \mathrm{~mm}$ cell size. This may be due to the increase in cell size gave better entry to the setts compared to $38.5 \mathrm{~mm}$ cell size. The filling efficiency was higher at the medium peripheral speed of metering drum at $0.26 \mathrm{~m} / \mathrm{s}$ for both the sizes of the cells compared to the low $(0.13 \mathrm{~m} / \mathrm{s})$ and high peripheral speed of metering drum $(0.7 \mathrm{~m} / \mathrm{s})$. In the low peripheral speed of metering drum $(0.13 \mathrm{~m} / \mathrm{s})$, cassava picking time between the flute and sett was high.

Hence, the flute tries to pick two cassava setts at one entry and two setts complete to fill the flute, which results in failure to fill the cassava sett in the flute. Whereas at higher peripheral speed, the available picking time by each flute to accommodate the sett was reduced, resulting in failure to pick up the sett and hence the filling efficiency got reduced significantly (Fig. 4).

Table.1 Cassava stem diameter (mm) of different varieties commonly cultivated in Tamil Nadu

\begin{tabular}{|r|c|c|c|c|}
\hline Diameter & Yethapur & Srivijaya & $\mathbf{C O}_{\mathbf{4}}$ & Cumcumarose \\
\hline Minimum(mm) & 31 & 30 & 27 & 30 \\
\hline Maximum(mm) & 35 & 34 & 35 & 35 \\
\hline
\end{tabular}

Table.2 Diameter ( $\mathrm{mm}$ ) of fluted roller type cells selected

\begin{tabular}{|c|c|}
\hline $\begin{array}{l}\text { Sl. } \\
\text { No. }\end{array}$ & $\begin{array}{l}\text { Maximum sett } \\
\text { dimension }(\mathbf{m m})\end{array}$ \\
\hline $\mathbf{1}$ & $35 \mathrm{~mm}$ \\
\hline
\end{tabular}

$135 \mathrm{~mm}$
10 percent more than maximum sett dimension (a') (mm) $38.5 \mathrm{~mm}$
25 percent more than maximum sett dimension (b') (mm) 
Table.3 Filling efficiency at various peripheral speeds for cell size 38.50mm (having 10 per cent more than the maximum sett dimensions

\begin{tabular}{|c|c|c|c|c|c|c|c|}
\hline \multirow{2}{*}{$\begin{array}{c}\text { Duration } \\
\text { of run,t } \\
\text { (min) }\end{array}$} & \multirow{2}{*}{$\begin{array}{l}\text { Metering } \\
\text { drum } \\
\text { rev/min } \\
\text { (N) }\end{array}$} & \multirow{2}{*}{$\begin{array}{c}\text { Peripheral } \\
\text { speed of } \\
\text { metering drum } \\
\mathrm{V}=\Pi \times \mathbf{D} \times \mathbf{N} / \mathbf{6 0} \\
\mathrm{m} / \mathrm{s}\end{array}$} & \multirow{2}{*}{$\begin{array}{c}\text { Number of } \\
\text { setts } \\
\text { expected to } \\
\text { be metered } \\
c_{\mathrm{e}}=2 \mathrm{Nt}\end{array}$} & \multicolumn{3}{|c|}{$\begin{array}{l}\text { Actual number of setts } \\
\text { metered } c_{a}\end{array}$} & \multirow{2}{*}{$\begin{array}{c}\text { Average } \\
\text { Filling } \\
\text { efficiency } \\
\left(c_{a} / c_{e}\right) \times 100 \\
(\%)\end{array}$} \\
\hline & & & & $\mathrm{R}_{1}$ & $\mathrm{R}_{2}$ & $\mathrm{R}_{3}$ & \\
\hline 1 & 10 & 0.13 & 20 & 6 & 10 & 8 & 40 \\
\hline 1 & 15 & 0.20 & 30 & 14 & 12 & 15 & 45 \\
\hline 1 & 20 & 0.26 & 40 & 18 & 20 & 19 & 48 \\
\hline 1 & 25 & 0.33 & 50 & 21 & 22 & 20 & 42 \\
\hline 1 & 30 & 0.39 & 60 & 21 & 23 & 22 & 37 \\
\hline 1 & 35 & 0.46 & 70 & 26 & 25 & 27 & 37 \\
\hline 1 & 40 & 0.52 & 80 & 26 & 28 & 27 & 34 \\
\hline 1 & 45 & 0.59 & 90 & 25 & 25 & 25 & 28 \\
\hline 1 & 50 & 0.65 & 100 & 23 & 24 & 22 & 23 \\
\hline 1 & 55 & 0.72 & 110 & 20 & 22 & 21 & 19 \\
\hline
\end{tabular}

Table.4 Filling efficiency at various peripheral speeds for cell size $42.50 \mathrm{~mm}$ (having 25 per cent more than the maximum sett dimensions

\begin{tabular}{|c|c|c|c|c|c|c|c|}
\hline \multirow{2}{*}{$\begin{array}{c}\text { Duration } \\
\text { of run,t } \\
(\mathbf{m i n})\end{array}$} & \multirow{2}{*}{$\begin{array}{l}\text { Meteri } \\
\text { ng } \\
\text { drum } \\
\text { rev/mi } \\
\text { n } \\
(\mathbf{N})\end{array}$} & \multirow{2}{*}{$\begin{array}{c}\text { Peripheral } \\
\text { speed of } \\
\text { metering } \\
\text { drum } \\
\mathbf{V}=\Pi \times \mathbf{D} \times \mathbf{N} / 60 \\
\mathbf{m} / \mathbf{s}\end{array}$} & \multirow{2}{*}{$\begin{array}{l}\text { Number of } \\
\text { setts } \\
\text { expected to } \\
\text { metered } \\
c_{\mathrm{e}}=2 \mathrm{Nt}\end{array}$} & \multicolumn{3}{|c|}{$\begin{array}{l}\text { Actual number of } \\
\text { setts metered } c_{a}\end{array}$} & \multirow{2}{*}{$\begin{array}{c}\text { Average } \\
\text { Filling } \\
\text { efficiency } \\
\left(c_{a} / c_{e}\right) \times 10 \\
0 \\
(\%)\end{array}$} \\
\hline & & & & $\mathrm{R}_{1}$ & $\mathrm{R}_{2}$ & $\mathrm{R}_{3}$ & \\
\hline 1 & 10 & 0.13 & 20 & 10 & 10 & 9 & 50 \\
\hline 1 & 15 & 0.20 & 30 & 18 & 16 & 15 & 53 \\
\hline 1 & 20 & 0.26 & 40 & 23 & 22 & 24 & 58 \\
\hline 1 & 25 & 0.33 & 50 & 28 & 27 & 29 & 56 \\
\hline 1 & 30 & 0.39 & 60 & 32 & 34 & 33 & 55 \\
\hline 1 & 35 & 0.46 & 70 & 36 & 37 & 35 & 51 \\
\hline 1 & 40 & 0.52 & 80 & 37 & 38 & 40 & 48 \\
\hline 1 & 45 & 0.59 & 90 & 31 & 32 & 32 & 36 \\
\hline 1 & 50 & 0.65 & 100 & 33 & 32 & 34 & 33 \\
\hline 1 & 55 & 0.72 & 110 & 35 & 38 & 36 & 33 \\
\hline
\end{tabular}


Table.5 Analysis of variance for filling efficiency based on cell size and peripheral speed

\begin{tabular}{|c|c|c|c|c|c|}
\hline Source & $\begin{array}{c}\text { Type III Sum of } \\
\text { Squares }\end{array}$ & df & $\begin{array}{c}\text { Mean } \\
\text { square }\end{array}$ & F & Sig. \\
\hline Corrected Model & $7041.400^{\mathrm{a}}$ & 19 & 370.600 & 37.88 & .000 \\
\hline Intercept & 102011.267 & 1 & 102011.267 & 10374.027 & .000 \\
\hline $\mathbf{C}$ & 2160.000 & 1 & 2160.000 & 219.661 & $.000^{* *}$ \\
\hline $\mathbf{S}$ & 4728.067 & 9 & 525.341 & 53.424 & $.000^{* *}$ \\
\hline $\mathbf{C} * \mathbf{S}$ & 153.333 & 9 & 17.037 & 1.733 & $.113 \mathrm{NS}$ \\
\hline Error & 393.333 & 40 & 9.833 & & \\
\hline Total & 109446.000 & 60 & & & \\
\hline Corrected Total & 7434.733 & 59 & & & \\
\hline
\end{tabular}

**Significant at $1 \%$ probability level

Fig.1 Orthographic and isometric views of the fluted roller metering mechanisms with Dimensions (mm)

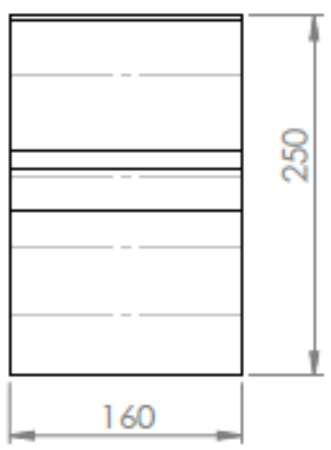

Front view

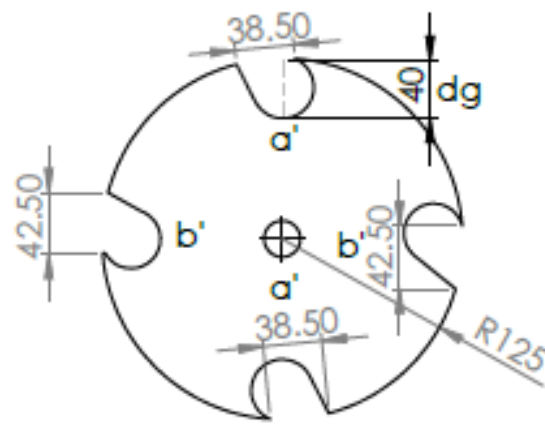

Side view

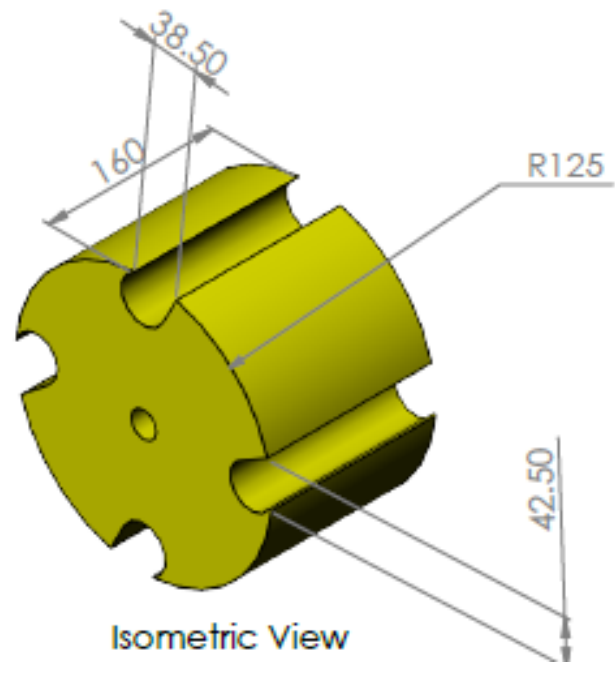


Fig.2 Isometric view of the complete cassava metering test rig
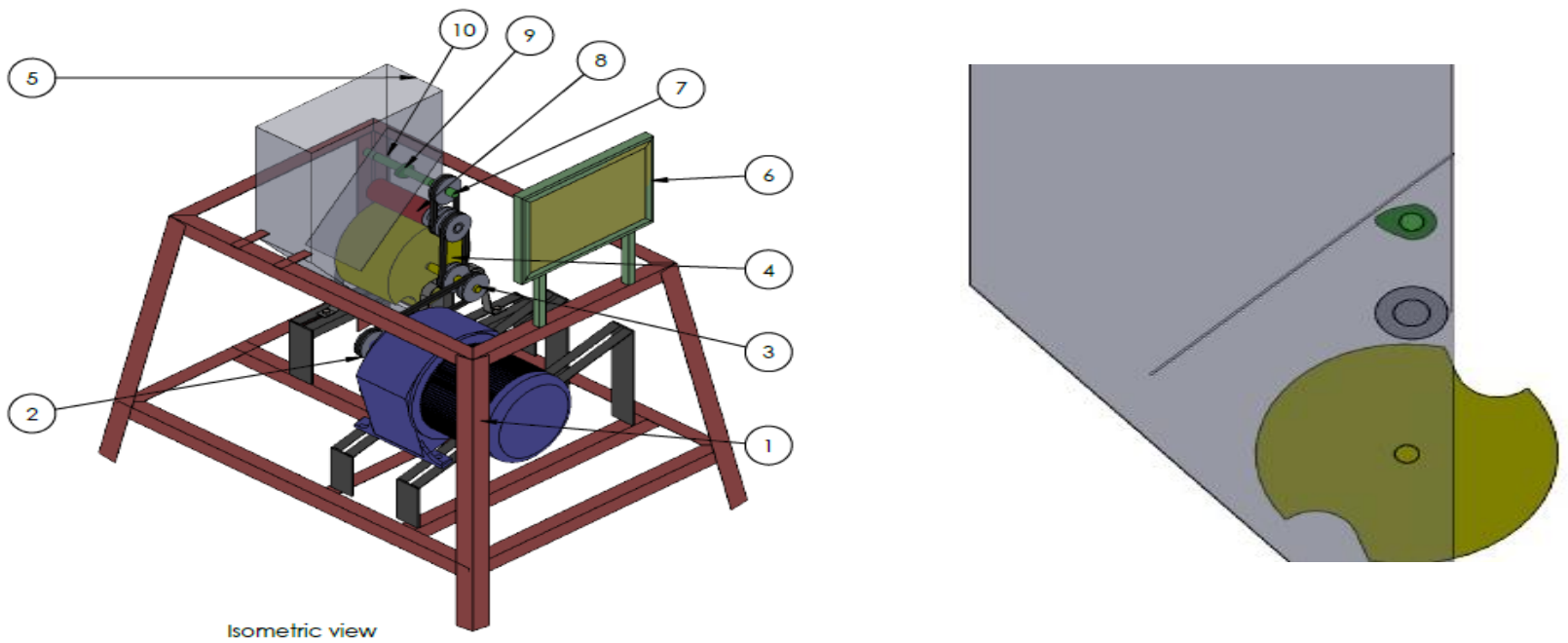

Main frame 2.Varible speed drive motor 3.Metering Shaft 4.Meterin Drum 5.Hopper 6. Speed control board 7.Camshaft 8.Foam Roller 9.Cam 10.Agitation feed trough

Fig.3 Laboratory model of cassava metering test rig
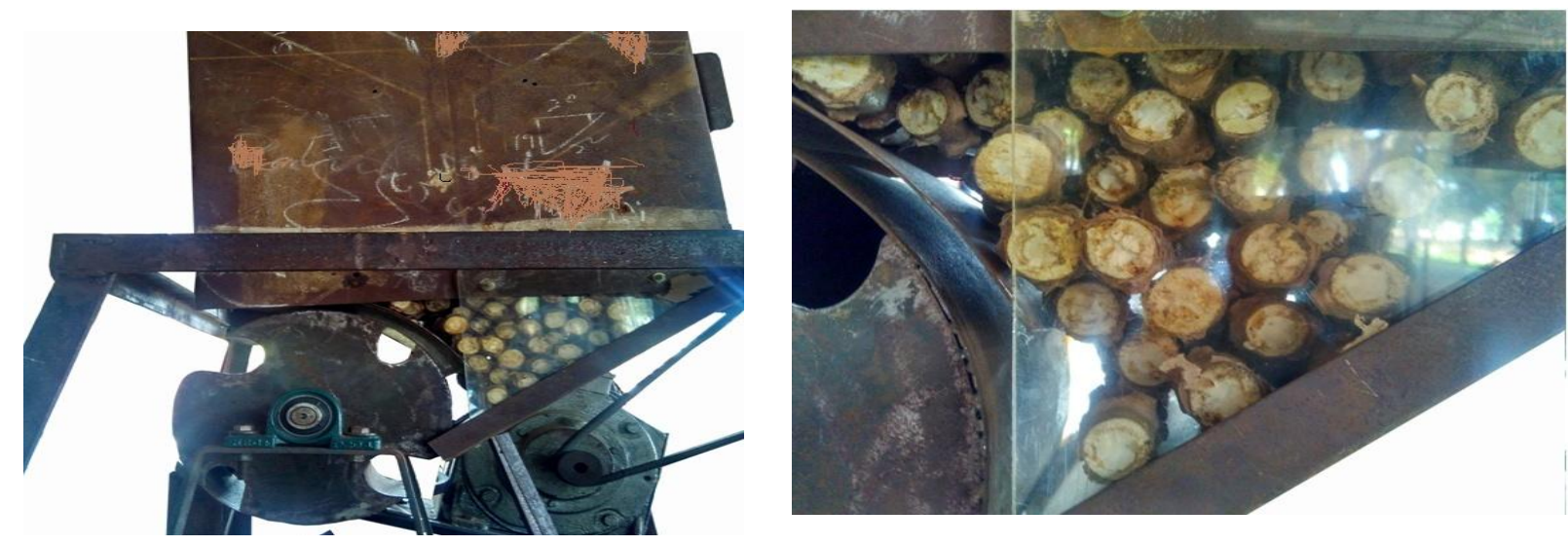

Fig.4 Comparison of filling efficiency of different cell sizes

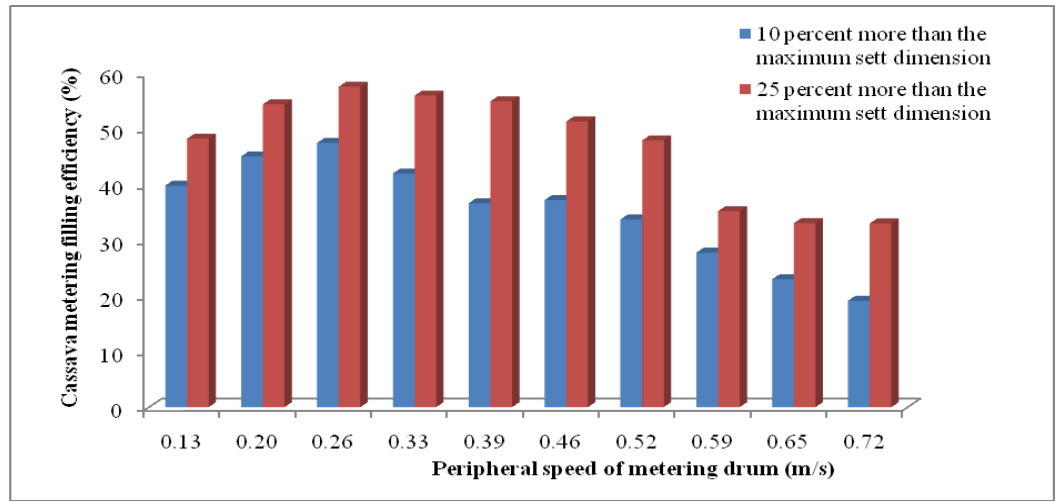


The laboratory results were statistically analyzed with SPSS version 25 for assessing the effect of the variables (cell size, peripheral speed of metering disc). The main effect of cell size and peripheral speed were highly significant $(\mathrm{P}<0.01)$ at $1 \%$ probability level. However the interaction of the cell size with the peripheral speed of metering flute was not significant (Table 3-5).

In conclusion, filling efficiency was increased from initial selected speed range to certain level $(0.13$ to $0.26 \mathrm{~m} / \mathrm{s})$ and then filling efficiency decreased with increased peripheral speed of fluted roller. The maximum filling efficiency obtained was $58 \%$ at peripheral speed of 0.26 $\mathrm{m} / \mathrm{s}$ and cell size of $42.50 \mathrm{~mm}$ is important for designing fluted roller metering mechanism for cassava sett planter.

\section{References}

Ahmadi, E., H.R. Ghassemzadeh, M. Moghaddam and Kim, K.U. 2008. Development of a precision seed drill for oilseed rape.Turkish Journal of Agriculture and Forestry, 32(5), pp.451458
Boydas, M.G and Turgut, N. 2007. Effect of vibration, roller design, and seed rates on the seed flow evenness of a studded feed roller. Applied Engineering in Agriculture. 23: 413-418.

Farooq, M., S.I. Ahmad and Majid, A. 1992. Developments in mechanical planting of sugarcane. Agricultural Mechanical in Asia, Africa and Latin America, 23(1), pp.29-32.

Odigboh, E.U. 1978. A two-row automatic cassava cuttings planter: Development, design and prototype construction. Journal of Agricultural Engineering Research, 23(2), pp.109-116.

Pandi, M.D., D. Asokan, J. J. Gunasekar, and Kannan, V. 2017. Influence of Physical properties of Cassava Setts on CoEfficient of Static Friction. International Journal of Agriculture Sciences, 9(48), pp.-4806-4809.

Ryu, I. H and Kim, K.U. 1998. "Design of roller type metering device for precision planting." Transactions of the ASAE 41, no. 4 (1998): 923.

Varmudy, V. 2014. Cassava cultivation and export: vast scope in India.

\section{How to cite this article:}

Dinesh Pandi, M., D. Asokan, J. John Gunasekar and Vallal Kannan, S. 2019. Assessing Suitability of Fluted Roller Metering Mechanism for Cassava Setts Planter. Int.J.Curr.Microbiol.App.Sci. 8(05): 1951-1957. doi: https://doi.org/10.20546/ijcmas.2019.805.226 